\title{
Women's Role in Organizational Commitment and Job Satisfaction in the Travel Industry-An Evidence from the Urban Setting
}

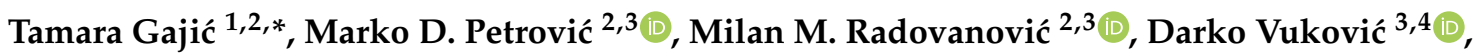 \\ Darko Dimitrovski ${ }^{5}$ and Natalia V. Yakovenko ${ }^{6}$ (i) \\ 1 Faculty of Sport and Hotel Management, Singidunum University, 11000 Belgrade, Serbia \\ 2 Institute of Sports, Tourism and Service, South Ural State University, 454080 Chelyabinsk, Russia; \\ m.petrovic@gi.sanu.ac.rs (M.D.P.); m.radovanovic@gi.sanu.ac.rs (M.M.R.) \\ 3 Geographical Institute "Jovan Cvijić" SASA, 11000 Belgrade, Serbia; vdarko@hotmail.rs \\ 4 Department of Economics and Industrial Engineering, Perm National Research Polytechnic University, \\ 614990 Perm, Russia \\ 5 Faculty of Hotel Management and Tourism, University of Kragujevac, 36210 Vrnjačka Banja, Serbia; \\ darko.dimitrovski@kg.ac.rs \\ 6 Research Institute of ITLK of Voronezh, State University of Forestry and Technologies, \\ 394018 Voronezh, Russia; n.v.yakovenko71@gmail.com \\ * Correspondence: tamara.gajic.1977@gmail.com
}

check for updates

Citation: Gajić, T.; Petrović, M.D.; Radovanović, M.M.; Vuković, D.; Dimitrovski, D.; Yakovenko, N.V. Women's Role in Organizational Commitment and Job Satisfaction in the Travel Industry-An Evidence from the Urban Setting. Sustainability 2021, 13, 8395. https://doi.org/ $10.3390 /$ su13158395

Academic Editor: Alastair M. Morrison

Received: 22 June 2021

Accepted: 14 July 2021

Published: 27 July 2021

Publisher's Note: MDPI stays neutra with regard to jurisdictional claims in published maps and institutional affiliations.

Copyright: (c) 2021 by the authors. Licensee MDPI, Basel, Switzerland. This article is an open access article distributed under the terms and conditions of the Creative Commons Attribution (CC BY) license (https:// creativecommons.org/licenses/by/ $4.0 /)$.

\begin{abstract}
Employee satisfaction is the main factor achieving high work performance, providing quality services in the tourism sector, which directly affects the increase in productivity and commitment to the organization. The research is focused on determining the factors of job satisfaction and commitment to the institution by the female workforce. The authors conducted a survey in tourism companies in Novi Sad (the second-largest city in Serbia), based on a sample of 610 women in total, using a standardized MSQ questionnaire for job satisfaction, and Meyer and Allen's organizational commitment scale. Three multiple regression analyses were used to determine the relationship between job satisfaction factors and organizational commitment factors. The results confirm the existence and strength of correlation between satisfaction factors and types of organizational commitment, and the fact that the position of women in the tourism sector is not at an enviable level, and that they remain in the same organization because of the small number of alternatives and moral obligations.
\end{abstract}

Keywords: job satisfaction; organizational commitment; tourism; women; Novi Sad

\section{Introduction}

The participation of the female workforce in tourism in the world is clearly visible. The intensity of work within the tourism sector is considered to be a significant source of employment and job creation for the younger population, women and migrants. The employment rate of women in tourism in many countries of the world is far above their employment in other sectors of the economy. The International Labor Organization (ILO) reports that on a global scale the share of women in tourism was $55.5 \%$ in 2013 , and in certain regions this share is as high as 70\%. According to statistics in Serbia, the majority of staff in the tourism industry are women, a total of $61.54 \%$. Until the appearance of Covid-19, it could be said that tourism is an economic branch of the future of Serbia. However, the pandemic had severe consequences for all economic branches, and especially for tourism. Many lost their jobs, many tourist companies were closed completely. In recent years, large tourism organizations have put employee satisfaction at the forefront, and explored factors that will influence the creation of high commitment by employees. Furthermore, leaders are aware of the importance of employees for their own business, understanding 
the direct impact that employees have on productivity and service efficiency. There are a large number of research papers on similar topics, but very few papers that have covered the female workforce in researching job satisfaction and organizational commitment. With that, the authors approached the idea of researching the labor market of tourist companies, exclusively female labor. The aim of the research was to reveal the dimensions of the job satisfaction and types of organizational commitment and to determine the extent to which satisfaction factors (internal and external) correlate with types of organizational commitment. The research was conducted in Novi Sad, during 2019, in tourist companies, on a total sample of 610 women, who made up the leading workforce. The final results of this research indicated that there is a correlation between satisfaction factors and types of organizational commitment, but also indicate a very poor position of women in the tourism sector, who due to the small number of alternatives and moral obligations remain in the same organization.

The significance of this research is to find factors that will affect employee satisfaction and loyalty, especially when it comes to women. In Serbia, women are put in the background when it comes to employment. In recent years, projects have been organized where women try to get involved in the tourism sector, in order to avoid prejudice, and be stimulated to contribute to the family and their personal satisfaction. The paper emphasizes the position and satisfaction of the female workforce, because the highest percentage of women employed in the tourism sector was recorded. The originality of this research work can help empower women at work and create strategic measures to improve the work environment in Serbia. The question is which will be largely the topic of future research, and that is what factors will affect job satisfaction and commitment to the organization. Given the significant job losses, women will largely stay at work due to lack of other job opportunities, and the level of factors that will affect satisfaction will certainly go down. Nowadays, it is very difficult for women to achieve and reconcile work and family functions, because they do not have sufficient support from institutions.

\section{Literature Review}

\subsection{Gender Theory and Women's Participation in Tourism}

Gender theory as a social structure must clarify certain phenomena in organizations with attention to gender implications. Gender is deeply embedded as a basis for stratification not only in our personalities, our cultural rules or institutions, but in all of these, and in complicated ways [1-3]. Gender structure distinguishes gender-based opportunities and constraints, and this has consequences in three dimensions: (1) at the individual level for the development of the gender self; (2) during the interaction, how men and women face different cultural expectations even when they fill identical structural positions; and (3) in institutional domains where explicit regulations on the distribution of resources and material goods are gender-specific [4-6]. Agency theory is a theoretical approach to an enterprise that explains the complex relationships, actors, interests and goals of an enterprise through an agency relationship, that is, a contract in which one or more principal(s) hires another person(s) to do a certain job, giving them the authority to make some key decisions. With the development of the company, these relationships become more complex, and management emerges as the principal agent of the owner or the original principal and assumes his role in relation to the employees [7]. This theory is an important explanatory instrument in economics and finance, and is a good basis and framework for considering the interests, goals and relationships of shareholders, management and employees, as well as many processes within the organization in promoting and achieving them [8]. The problem of female workforce employment is certainly a driving force for research, and such research can contribute to a broader perspective on the issue and influence structural change for better business. Public perceptions of the enviable status and position of women in tourism are masked by non-transparent data and statistics that speak in favor of employment growth in the sector, record earnings and economic impacts, such as the share of tourism revenue in national GDP [9]. Through labor rights and employers' attitudes towards them, 
the dimensions of gender discrimination (unequal position of women in this sector, and in society in general) are shown, as well as the complexity of their position within the tourism and hospitality sector [10]. As for women themselves and their status, the fact is that more women than men work in this industry [11]. However, it is also true that they are employed in low-paying jobs [12]. There is evidence that women's participation in the services sector has improved, both quantitatively and qualitatively, but undoubtedly, they continue to encounter some obstacles that reflect labor market discrimination [13]. However, as the participation rate of women in the labor market increases, their working conditions are less favorable than men's [13], and are therefore mostly in these low-quality and less valued jobs $[14,15]$. Accoding to Pleck [16] women in Turkey suffer injustice due to social norms and prejudices and the lower position of women in society in relation to men.

The participation of women in the business world of tourism has increased in recent years, and there has even been an increase in the share of women in management and leadership. The tourism industry has always been considered a sector that employs a lowskilled workforce and offers low-paid jobs. A similar study on the participation of women in the tourism sector of Karnataka in India [17]. The obtained data indicate that in the tourism industry, the percentage of women working in the industry is increasing, but their function is dominated by unskilled, low-paid jobs. In her research, she pointed out the importance of tourism in the great contribution of women's employment. Accor hotel groups launched a program in 2011, in which it employs over 160.000 people in 3.500 hotels in 92 countries around the world. They brought the "Charter on Diversity", which emphasizes the fight against prejudice and stereotypes, and thus the goal of achieving equality for women in the tourism sector. That year, the percentage of employed women was 50\%. However, only $27 \%$ of women were in the hotel management sector, and $13 \%$ of directors (https:/ / sites. google.com/a/nf-int.org/digitale-bibliothek/home/tourismus/dossiers, accessed on 16 May 2021). According to Alrwajfah et al. [18] point out that there are barriers to women's empowerment and employment in tourism, and show that women do not have a favorable view of the economic impacts of tourism. Interesting study called "Women's participation and Tourism industry", gives an overview that India employs a large number of women in the tourism sector, but the gender ratio has almost reached a level playing field [19]. By the data of census the current Sex Ratio of India in 2015 is 943 Females/1000 Males. In a paper entitled "Woman Empowerment through Entrepreneurship in Service Sector with special Reference to SHGs in Tourism", are shown data on the increasing participation of women in tourism, especially in the rural tourism development sector in India [20]. According to research which was provide in in a paper called "Women in Turkish tourism", show results indicating that with the development of tourism in Turkey, women overcame prejudices, broke away from tradition, and first started working in their homes, becoming strengthened both economically, socially and individually by entering the business and using the opportunities provided by tourism [21].

Similar research on women's empowerment has been conducted in the following countries: Egypt, the United Arab Emirates and Oman [22]. In a total sample of 784 female respondents, they found that perceptions of women's work in tourism and women's entrepreneurship are significant predictors of women's empowerment in the tourism sector. The United Arab Emirates ranks first in the impact of women's empowerment on tourism development. A group of authors in their study entitled "Perceptions of Women's Empowerment in Ramsar, a Tourist Destination in Northern Iran", identified 10 unique perceptions of women"s empowerment in tourism [23]. They also emphasize that they must not neglect the sociocultural aspects of empowerment, the extent to which women perceive themselves as empowered. According to Boley et al. [24]. The increasing participation of women in tourism has been confirmed. They emphasize the intercultural validity of resident empowerment through the tourism scale (RETS) in the city of Oizumi, Japan. The poor position and participation of women in tourism is influenced by marginal, but also feminist postcolonial, political poststructuralist approach that prevails in the country [25]. 


\subsection{Job Satisfaction and Organizational Commitment}

Job quality in the broadest sense encompasses employment and job characteristics (hours, salaries, skills required), general work environment and the labor market (working conditions, training, equal opportunities, social dialogue) and subjective perception or appraisal of their job (job satisfaction, career expectations) [26]. Insufficient research and attention to this part of the business is often an indicator of failure to respond to modern market trends. An employee who is the potential holder of the idea as of a change, depending on their will, can become motivated enough to put in the effort in the day-today business, can become the one who begins to align his interests with the interests of the company where they are employed, and does not intend to leave it as long as it responds to his demands and challenges him [27,28]. Equality theory proposed by Mercurio [29], built on the belief that employees become demotivated about their job and their employer if they feel their inputs (hard work, loyalty, commitment, skills, ability, flexibility, tolerance, enthusiasm, trust in leaders, support colleagues, dedication), are much greater than outputs (financial rewards, accolades, reputation, responsibility, sense of advancement and personal development, compassion for achievement, praise, incentives, job security) [30]. Employees respond to this "unjust" disparity in various ways, including low motivation, reduction of work effort (down to the level that the employee considers parity with the rewards he receives), open expression of dissatisfaction, reduced loyalty until "diversion", damage to the employer [31-33]. Research shows that the most dissatisfied are young people [34-36]. They have no work experience and do not yet know what looking for a job really looks like, they have high expectations, because they have just finished their education, their salary is the lowest, and there are generally a greater number of superiors above the firm's hierarchy. As working life increases, people are more and more satisfied with their jobs, and before retirement, interest in work decreases, and therefore dissatisfaction increases [37]. Additionally, each truth has two sides, so the situation should be seen through the eyes of employers. It is not only a question of how much a worker is given when performing a job, it is also a question of what the job offers to employees [38].

In the existing literature, commitment to the organization, job satisfaction and involvement in the business is considered to be the most significant and the most researched attitude towards business [39-41]. To begin with, consideration of a construct within an organization is characterized by a view of commitment to behavior [42]. Research starts from Becker's side-betting model [41], and the model of commitment suggested by Mowday et al. [43]. The last era is the most famous and well-researched multidimensional model of Meyer and Allen [44,45]. The beginning of model development is related to their earlier research [46] in which they claim that commitment to the organization is referred to as affective commitment. The same authors concluded that it is a multidimensional construct, starting from different definitions of commitment to the organization. They also propose their operationalization of Becker's [47] approach and call it a lengthy, instrumental commitment. The authors conceptualized affective and instrumental commitment as two independent dimensions, that is, types of commitment to the organization. They emphasize that these two forms of commitment are independent. That is, the level at which it is affectively attached does not determine the degree to which it is instrumentally committed, and vice versa. Drawing on the results of their 1987 research, in a 1990 article, they present a three-dimensional model of commitment, as well as scales for measuring it. In addition to affective and instrumental commitment, they also define normative commitment. The validity of a three-dimensional model of commitment to an organization has been tested in many studies [48-51]. Some theorists argue that affective and normative commitment are mutually positive and independent of instrumental commitment. Criticism has also emerged in this model, on the emergence of overlapping normative and affective dimensions, as well as the multidimensionality of the instrumental model $[52,53]$. Some authors claim that it is necessary to "refine the construct" and adequately define it as a one-dimensional psychological state or connection, regardless of the purpose or purpose of the commitment. Commitment is more than just a passive stay, and it is a will- 
ingness for an individual to commit to and take responsibility for the organization [54]. The one-dimensional commitment model is positively and highly associated with an affective, moderately with a normative, commitment, while not being significantly associated with instrumental commitment from the Meyer and Allen model.

According to Kehoe et al. [55], more unambiguous and non-conflicting the expectations and demands of the role are, the more affective the employees will be. When it comes to the antecedents of instrumental commitment to the organization, there is far less research than there is about affective commitment, because the affective dimension is the essence, the essence of commitment to the organization. Satisfaction is a pleasant or positive emotional state resulting from a job evaluation or job experience. It arises as a result of the employee's perception that the job they are performing has the ability to fulfill his essential business values and to enable those values to be aligned with their own needs [56]. Job satisfaction can also be understood as the degree of alignment between what an organization requires from employees and what it provides them with, on the one hand, and what employees expect from an organization, on the other. Job satisfaction is influenced by several factors: working conditions, salary, working atmosphere, interpersonal relationships, quality of communication, personal compliance, etc. [57,58] The findings so far suggest that overall job satisfaction is closer to intrinsic motivation, professional interests and expectations, and a more general relationship to job type [59-62]. Emphasis is placed on actively managing their potential, and in the context of advancing the use of human factors, various schemes are being developed to increase motivation to work [63-67]. Satisfaction affects productivity on some other phenomena such as organizational commitment [68-71]. Very interesting structural model of organizational commitment that assumed that there was a link between job involvement, job satisfaction and organizational commitment, developed by Kuruuzum [72]. In recent studies, Khan and Nemati [73] and Yeh [74] are unequivocal in their claim that job involvement has a significant positive impact on job satisfaction. Within the model, job involvement is linked to organizational commitment, which in turn affects job satisfaction [75]. Three dimensions of organizational commitment were highlighted by Meier and Allen [76] while Robbins and Judge [77] argued that they define each dimension starting with affective commitment (the degree to which an employee identifies with a particular organization and its goals and desires to retain organizational membership), specifically, employees stay in their workplace because they want to. It must be emphasized that commitment to leadership and the organization itself are interactive: commitment to the organization often results from a commitment to leadership, while commitment to leadership can be a consequence of commitment to the organization $[78,79]$. As with most psychological constructs, there are many different definitions of commitment. According to Sheldon commitment to an organization can be viewed as an attitude or orientation towards an organization that connects or binds an individual's identity to the organization. Organizational commitment was addressed by Meyer and Allen [80] who formed the three-factor scale of organizational commitment and argued that organizational commitment influences employees' decision to remain in an organization. They emphasized affective (emotional), continuous (willingness to remain in the organization) and normative commitment (obligatory commitment to the organization) [81]. Some authors used commitment measures operationalized through different approaches in their meta-analytic study [82]. The authors divided the predictors of commitment into five groups, where the first refers to employees' personal characteristics (gender, work experience, values, and so on), which will not be shown in this section of the text, while the other four groups relate to job characteristics, relationships between leader and group, organization characteristics and role status. Seven categories of lateral roles were investigated by Powell and Meyer [83], and in their research contributed to Becker's conceptual model of attachment. In their research, they came to the conclusion that all seven categories of lateral roles are associated with organizational commitment and a constant need for sacrifice. In tourism, the role of women is often extended to their domestic responsibilities and there is little compromise on life-choice issues. Some theo- 
rists see the value, in terms of conscious managerial practice, of claiming that employers are harnessing the social and domestic skills that women acquire through gender role socialization and employing women for jobs that include cleaning, serving and caring for children [84]. There are studies that make it clear that the relationship and position at work is closely related to those of family. Many authors have dealt with this current topic, which is given in Table 1.

Table 1. Related works.

\begin{tabular}{cc}
\hline \multicolumn{1}{c}{ Dimensions } & Authors \\
\hline Gender Equality; Women's Participation & {$[6,11,12,14,15,31,53-56,59,68-70]$} \\
\hline Job Quality and Satisfaction; Organizational Commitment & {$[28,29,32,33,57,58,64,68,71-74]$} \\
\hline
\end{tabular}

The research entitled "Job Satisfaction, Organizational Commitment and Involvement in Work: The Mediating Role of Involvement in Work", presented a survey conducted among 566 respondents in Serbia, where the authors concluded that employees are mainly affected by work habits, as well as organizational policies and procedures do. do not significantly affect employee satisfaction [85]. Transformational leadership cannot give significant impact to work performance [86]. The research was performed in Indonesia.

Sexual segregation has been shown to be prone to locating women in areas that are considered less qualified and therefore less valuable to the economy [87]. The starting hypotheses of the research were set as:

Hypothesis 1 (H1). There is a strong correlation between satisfaction factors and types of organizational commitment among women employees in tourism enterprises.

Hypothesis 2 (H2). There is a visible difference between the types of organizational commitment among female respondents employed in tourism enterprises.

\section{Methodology}

The survey was conducted in Novi Sad, in the period August-October 2019. The survey included a sample of 610 women, who were employed in various tourism sectors. For the purpose of conducting this research, two questionnaires were used-the Job Satisfaction Questionnaire (Minnesota Job Satisfaction Questionnaire) and the Organizational Commitment Scale (Meyer and Allen), which were distributed to employees, and participation in the survey was anonymous. The bibliographic-speculative method was used in collecting, analyzing and interpreting the obtained data, or for structuring the theoretical part of the paper. The statistical method was applied in the mathematical processing of empirical material, that is, the results obtained from the questionnaires after completing the information collection were statistically processed, using the Statistical Package for Social Sciences Version 23.00-SPSS. The factors of satisfaction in the research are divided into three groups, proposed by Chuang et al. [88]:

1. Intrinsic factors (use of one's own abilities, activity, achievement, authority, creativity, independence, moral values, responsibility, job security, social utility, social status, diversity; 2. Extrinsic factors (relationships of supervisors) with subordinates, supervisor competence, organization policy and practice, compensation-relationship between salary and amount of work completed, advancement, recognition for a job well done; and 3. Factors of general satisfaction (all intrinsic and eccentric with two other aspects: associates and working conditions).

The research instrument consisted of two distinct sections. The first part of the survey used the Minnesota Job Satisfaction Questionnaire (MSQ), where respondents were asked to express a level of satisfaction for 20 specific aspects of the job, using a five-point Likert scale. The second included tools for measuring organizational commitment using Meyer and 
Allen's [89] Organizational Commitment Scale, which consists of 24 items (each containing eight statements of commitment). The analysis of descriptive indicators was performed for commitment to organization and job satisfaction. Three multiple regression correlations were performed to determine the correlation between satisfaction factors and types of organizational commitment.

\section{Results and Discussion}

Based on the results of the research (presented in Table 2), it is observed that in the total sample, most of them belonged to the age group from 31 to 40 years of age, a total of $37.9 \%$. The most common category of research was employed women with a total working experience of one to five years, and $37.4 \%$ had higher education or a university degree, while the smallest number of participants had the title of master or doctor of science, 3.3\%.

Table 2. Analysis of demographic characteristics (\%).

\begin{tabular}{|c|c|c|c|c|}
\hline \multicolumn{5}{|c|}{ Age Range } \\
\hline $20-30$ & $31-40$ & $41-50$ & \multicolumn{2}{|c|}{$50+$} \\
\hline $20 \%$ & $37.9 \%$ & $27.9 \%$ & \multicolumn{2}{|c|}{$14.3 \%$} \\
\hline \multicolumn{5}{|c|}{ Work Experience } \\
\hline Less than 1 & $1-5$ & $5-10$ & $10-15$ & More than 15 \\
\hline $20.3 \%$ & $27.7 \%$ & $14.6 \%$ & $20 \%$ & $17.4 \%$ \\
\hline \multicolumn{5}{|c|}{ Educational Level } \\
\hline High school & College & Faculty & \multicolumn{2}{|c|}{$\mathrm{MSc}, \mathrm{PhD}$} \\
\hline $34.3 \%$ & $25.1 \%$ & $37.4 \%$ & \multicolumn{2}{|c|}{$3.3 \%$} \\
\hline \multicolumn{5}{|c|}{ Work Place } \\
\hline Hotel & T. agency & T. guide & Managers & Chambermaid \\
\hline $27.2 \%$ & $34.9 \%$ & $21.8 \%$ & $8.5 \%$ & $7.5 \%$ \\
\hline \multicolumn{5}{|c|}{ School of Tourism Completed } \\
\hline & Yes & & \multicolumn{2}{|c|}{ No } \\
\hline & $53.4 \%$ & & \multicolumn{2}{|c|}{$46.6 \%$} \\
\hline \multicolumn{5}{|c|}{ Monthly Income (in Euros) } \\
\hline Under 200 & $201-300$ & $301-400$ & $401-500$ & Above 500 \\
\hline $11.3 \%$ & $35.1 \%$ & $35.6 \%$ & $7.4 \%$ & $10.7 \%$ \\
\hline
\end{tabular}

In the very description of sociodemographic characteristics, one notices the dilemma of how employed women, in the range of one to five years of employment, may feel a kind of attachment to an organization. Is this a sufficient period to create loyalty, and what factors affect their loyalty or change of a job? A total of $34.9 \%$ of research participants are employed in the workplace of travel agencies, followed by $27.2 \%$ in hotel facilities, $21.8 \%$ of them in the service of tourist guides, and only $8.5 \%$ in some of the managerial positions. Of the total number of respondents, $53.4 \%$ have education in the field of tourism and catering. When considering wages as a sociodemographic category, it can be observed that the largest number of women are with earnings in the range of 301 to 400 Euros per month, while the smallest number are with earnings of more than 500 Euros per month.

All research factors (intrinsic and extrinsic) are summarized in Table 3, where we can see the results of descriptive statistical analysis. It is noted that employed women, research participants, gave the highest average rating for factors of moral value (3.61), then the variety of tasks at work (3.54), the creativity they can express while working in an organization (3.61), social status and authority, with average scores above 3.5. The highest standard deviation value has a progression factor of 1.507 . The standard deviation 
indicates the smallest deviation from the arithmetic mean for the authority factor (0.694), which is otherwise rated as high by an average score of 3.83. The worst-rated factors are job recognition (2.99) and job compensation (2.52).

Table 3. Analysis of descriptive indicators (intrinsic and extrinsic, general satisfaction).

\begin{tabular}{|c|c|c|}
\hline Satisfaction Factors & $\mathbf{M}$ & SD \\
\hline Activity at work & 3.19 & 1.201 \\
\hline Independence in work & 3.18 & 1.206 \\
\hline A sense of job security & 2.93 & 1.159 \\
\hline Supervision (Human Resources) & 3.40 & 1.260 \\
\hline Moral values & 3.61 & 1.162 \\
\hline Social service & 3.23 & 1.103 \\
\hline Satisfaction with associates & 3.11 & 1.283 \\
\hline Supervision (technical support) & 3.45 & 1.273 \\
\hline Work conditions & 3.17 & 1.255 \\
\hline Diversity at work & 3.54 & 1.070 \\
\hline Creativity at work & 3.61 & 1.098 \\
\hline Using your own abilities & 3.30 & 0.985 \\
\hline Degree of responsibility & 3.51 & 1.444 \\
\hline Organization policy and practice & 3.08 & 1.352 \\
\hline Social status & 3.78 & 1.033 \\
\hline Acknowledgement of the work done & 2.99 & 1.298 \\
\hline Authority & 3.83 & 0.694 \\
\hline Achievement (job fulfilment) & 3.45 & 1.193 \\
\hline Compensation & 2.52 & 1.393 \\
\hline Possibility of progression & 3.01 & 1.507 \\
\hline
\end{tabular}

Note. M, arithmetic mean; SD, standard deviation.

Regarding organizational commitment factors, in Table 4, through the analysis of descriptive indicators, it can be seen that factors $\mathrm{A} 6$ and $\mathrm{A} 7$, with affective organizational commitment (1.82 and 1.81), have the highest ratings. At the same time, with these factors the standard deviation shows a deviation from the arithmetic value of $A 7=0.621$ and A6 $=0.881$. Employees emphasize that they enjoy discussing the organization in which they work, and have a clear attitude about not being attached to a given collective. Factor A8, concerning the issue of staying in one organization for the rest of the career, carries a weaker average score of 1.43 , with a standard deviation of 0.715 . In continuous organizational commitment, the K7 factor stands out, with an average score of 2.02. Participants in the research point out that they have no fear of leaving the institution where they are currently employed. Factor N4, which belongs to the group of normative factors, carries the highest average score of 2.14 (std. dev. 0.672), and it speaks to the fact that employees do not feel that they have to remain loyal to only one organization, which has inevitable connections with factor K7, from a continuous group of factors, and talks about the ease of leaving the organization. 
Table 4. Descriptive statistics for factors of organizational commitment.

\begin{tabular}{|c|c|c|}
\hline Organizational Commitment Factors & $\mathbf{M}$ & SD \\
\hline A1-Easy attachment to another organization & 1.35 & 0.688 \\
\hline A2-Emotional disconnection with the organization & 1.70 & 0.750 \\
\hline A3-Problems in the organization are personal problems & 1.35 & 0.866 \\
\hline A4-Organization has a lot of influence on me & 1.62 & 0.808 \\
\hline A5-I don't have a strong sense of belonging to an organization & 1.56 & 0.815 \\
\hline A6-I enjoy discussing the organization & 1.82 & 0.881 \\
\hline A7-Sensitivity to the collective & 1.81 & 0.621 \\
\hline A8-Stay in the organization for the rest of your career & 1.43 & 0.715 \\
\hline K1-Financial expenses if I leave the company & 1.53 & 0.695 \\
\hline $\mathrm{K} 2-\mathrm{No}$ reason to leave the organization & 1.60 & 0.689 \\
\hline K3-Remainder of personal wish organization & 1.65 & 0.872 \\
\hline K4-Lack of alternative influences leaving the company & 1.74 & 0.862 \\
\hline K5-Leaving the organization, personal injury & 1.58 & 0.823 \\
\hline K6-Leaving this organization, life changes & 1.70 & 0.782 \\
\hline K7-I am not afraid of the consequences of leaving the organization & 2.02 & 0.671 \\
\hline K8-It's hard to quit a job even when there's a desire & 1.38 & 0.666 \\
\hline N1-People often change jobs & 1.88 & 0.792 \\
\hline N2-Transitioning from one organization to another is not unethical & 1.67 & 0.782 \\
\hline N3 -There is no loyalty to just one institution & 1.81 & 0.856 \\
\hline N4-I have no opinion that I have to be loyal to only one institution & 2.14 & 0.672 \\
\hline N5-It's better when employees stay in one organization & 1.63 & 0.756 \\
\hline N6-I don't consider the value of being a member of an organization & 1.76 & 0.726 \\
\hline N7-Loyalty is very important & 1.71 & 0.889 \\
\hline N8-It's okay to move to another job when it comes up & 1.74 & 0.849 \\
\hline
\end{tabular}

Note. M, arithmetic mean; SD, standard deviation. A1-A8 affective, K1-K8 continuous, N1-N8 normative factors.

Considering the data in Table 5 leads to the conclusion that all the variables examined are distributed according to the normal distribution. The values of the slope and flattening coefficients range within the acceptable values $(-1.5<x<1.5)$. Scales were educated on a predetermined key for the questionnaires used.

Table 5. Analysis of descriptive indicators for job commitment and job satisfaction.

\begin{tabular}{ccccc}
\hline & M & SD & $\begin{array}{c}\text { Oblique Coefficient } \\
\text { (Skewness) }\end{array}$ & $\begin{array}{c}\text { Flattening } \\
\text { Coefficient (Kurtosis) }\end{array}$ \\
\hline Intrinsic satisfaction factors & 3.42 & 0.57 & -0.72 & 0.69 \\
\hline Extrinsic satisfaction factors & 3.07 & 0.56 & -0.16 & -0.80 \\
\hline General satisfaction & 3.29 & 0.54 & -0.64 & -0.76 \\
\hline Affective commitment & 2.77 & 0.71 & 0.60 & 0.13 \\
\hline Continuous commitment & 3.04 & 0.60 & -0.48 & -0.91 \\
\hline Normative commitment & 2.79 & 0.49 & 0.90 & 1.20 \\
\hline
\end{tabular}

Note. M, arithmetic mean; SD, standard deviation.

Since all variables were normally distributed, parametric statistics methods were used. Considering the arithmetic mean of the variables used, it is noticeable that all three types 
of commitment are much smaller than the theoretical arithmetic mean of the scales (3.00), which indicates that the respondents show low attachment to the job. Three multiple regression analyzes were used to examine the relationship between different aspects of job satisfaction (intrinsic factors, extrinsic factors and general satisfaction) and commitment (affective, continuous and normative). Different aspects of job satisfaction were predictor variables and different types of attachment were set as criterion variables (Table 6).

Table 6. Job satisfaction relationships and commitment to work.

\begin{tabular}{|c|c|c|c|c|c|c|}
\hline & \multirow{2}{*}{\multicolumn{2}{|c|}{$\begin{array}{c}\text { Affective } \\
\text { Commitment } \\
\begin{array}{c}F=148.06 \\
R^{2}=0.42\end{array}\end{array}$}} & \multirow{2}{*}{\multicolumn{2}{|c|}{$\begin{array}{c}\text { Continuous } \\
\text { Commitment } \\
\begin{array}{c}F=414.60^{* *} ; \\
R^{2}=0.67\end{array}\end{array}$}} & \multirow{2}{*}{\multicolumn{2}{|c|}{$\begin{array}{c}\text { Normative } \\
\text { Commitment } \\
\begin{array}{c}F=15.63^{* *} ; \\
R^{2}=0.07\end{array}\end{array}$}} \\
\hline & & & & & & \\
\hline & $\beta$ & $t$ & $\beta$ & $t$ & $\beta$ & $t$ \\
\hline Intrinsic satisfaction factors & 0.37 & $1.99 *$ & -0.67 & $-7.91^{* *}$ & 0.37 & 1.59 \\
\hline Extrinsic satisfaction factors & -0.05 & -0.62 & 0.27 & $2.68^{* *}$ & 0.01 & 0.11 \\
\hline General satisfaction & 0.44 & $4.40 * *$ & -0.41 & $-4.31 *$ & 0.22 & 2.06 * \\
\hline
\end{tabular}

Note. $F$, the value of the $F$-test; $R^{2}$, multiple determination coefficient. ${ }^{*} p<0.05 .{ }^{* *} p<0.01$.

The results of the first multiple regression analysis indicate that job satisfaction factors contribute significantly to affective job attachment. In fact, $42 \%$ of affective job attachment is determined by job satisfaction factors. Significant contributions to affective attachment are made by intrinsic satisfaction factors, and overall satisfaction in the positive direction. Therefore, employees who are driven by intrinsic satisfaction factors, as well as those who are generally more satisfied with the job, also exhibit greater affective attachment to the job, that is, they remain employees of the organization because they want it. When talking about continuous attachment, the results of multiple regression analysis show that $67 \%$ of this type of attachment is determined by job satisfaction factors. Significant contributions to continuous commitment are made by intrinsic factors of job satisfaction and general satisfaction withthe negative direction, but also by extrinsic factors of job satisfaction with the positive direction. In conclusion, it can be stated that employees who are less driven by intrinsic satisfaction factors, as well as those who are less satisfied with the job, remain employed in the workplace because they have to do so for certain reasons (material benefit, lack of employment alternative, etc.) Likewise, they are driven by more extrinsic satisfaction factors. The results of the last multiple regression analysis indicate that only $7 \%$ of normative commitment was explained by job satisfaction factors. As the only significant factor in normative commitment, overall job satisfaction turned out to have a positive direction. This means that the more employees are generally satisfied with their job, the more they will remain in that workplace for reasons of loyalty and moral obligation, or just because they feel it is right, since high job satisfaction can create an employee's sense of duty toward an organization where they are employed. The initial research hypotheses were confirmed. A strong correlation was found between job satisfaction factors and organizational commitment (H1), which was observed on the basis of the obtained research results. Furthermore, differences in types of organizational commitment are also evident (H2). The ratio of organizational commitment is such that continuous commitment has the highest value of 3.04, and is thus more pronounced in relation to affective and normative commitment.

Similar results were obtained by Mathur \& Salunke [90]. They emphasize that job satisfaction plays a significant role in achieving a committed workforce, in their research manusrcipt "Organizational commitment and Job Satisfaction: A study of Manufacturing", including a study conducted in Gwalior. According to Mabasa et al. [91] there is a significant positive relationship between job satisfaction and affective commitment, as well as continuous commitment, but a significant link between job satisfaction and normative commitment has not been established. In their paper "Determinant of Organizational Commitment among Women Employees in Malaysia", has been indicated the key prob- 
lems of women's commitment to work [90]. Their research emphasizes that women's multiple-role such as being a mother and a wife, among others, proved to be a hindrance to their career commitment. The fact that employee empowerment has a positive moderating impact on the relationship of organizational commitment with career satisfaction of female gender is confirmed by the research of authors Swati \& Shalini [91], who conducted and presented results in paper entitled "Organizational Commitment \& Career Satisfaction among Women Employees".

\section{Conclusions}

Tourism is considered to be a sector that employs more women as workforce, but it is known from various studies that they still occupy lower levels in organizational structures. Based on an increasingly topical theme, that satisfaction is inevitably linked to organizational commitment, the authors of the paper conducted a survey, but profiled only the female workforce in tourism organizations. The aim of the study was to determine the degree of satisfaction with pre-determined intrinsic and extrinsic satisfaction factors. Each type of organizational commitment, according to this scale, contains eight factors or statements, to which the research participants responded. The research hypotheses which were put forward were confirmed at the end of the data analysis. The largest percentage of employed women in the tourism sector is in the random ratio of one to five years, which is not relevant for the number of years of work experience in order to have strong reasons to be attached to the organization. It has been observed that all types of organizational commitment are much smaller than the theoretical arithmetic mean of the scales. The research participants showed relatively low commitment to the organization in which they work. Based on the results of the research, it was found that the factors of job satisfaction contribute to affective attachment, with the largest contribution from intrinsic satisfaction factors and overall job satisfaction in a positive direction. The conclusion was drawn that employees remain in the organizations as they wish. When looking at continuous organizational commitment, it is concluded that employees are driven by intrinsic factors. Only $7 \%$ of normative commitment was explained by job satisfaction factors. The employed women who participated in the research are generally satisfied with their jobs, and, moreover, they will remain loyal to the organization from moral obligations.

The modern business environment is characterized by high turbulence, uncertainty and risk, and for a company to survive in such an environment, it is necessary to continuously invest in human resources development and innovative activities. Many studies have emphasized the narrow relationship between job satisfaction and organizational commitment. People's values in the organization are strongly influenced by their values and attitudes. Both of these categories create a strong predisposition for people to act in a particular direction. If employees hold on to the value of flexibility and have a positive attitude towards change, it is very likely that they will respond positively to changes in the organizational structure, support them or give less resistance to them. Values and attitudes are related but not identical categories. A positive attitude will cause less absenteeism, better employee motivation and greater loyalty to the organization, while a second attitude will imply less commitment and motivation, greater absenteeism and a greater likelihood of leaving the job. Namely, organizational commitment represents positive attitudes that an employee feels not with their job, as in the case of job satisfaction, but with the organization as a whole or with some of its members. Organizational commitment indicates that employees have a deep commitment to the organization or some of its members. The three basic issues related to organizational attachment are attachment objects, basis or source of attachment and attachment effects. In order to anticipate one's job satisfaction, one must take into account not only satisfaction with the particular aspects of the job the individual is engaged in but also their expectations of that job. Overall job satisfaction is actually affected by the discrepancy or deviation of satisfaction from expectations regarding particular aspects of the job, not by the amount of satisfaction with those aspects per se. People have a tendency to associate the level of satisfaction with certain aspects of work with the amount of discrep- 
ancy between expectations and satisfaction. The term organizational commitment refers to positive attitudes that employees feel about their business and the organization as a whole. It implies a much stronger level of emotion towards an organization than job satisfaction. When studying organizational commitment, the commitment objects, the basis or source of commitment, and the effects of commitment are taken into account. It is very important to understand the commitment to the organization, as well as all the factors that determine the level of commitment. Particular emphasis is placed on job satisfaction as a significant indicator of job stimulation and the overall dimension of work. Job satisfaction is often seen in empirical research and practice as an important indicator of work motivation. The significance of this research is reflected in obtaining a more comprehensive view of the problem regarding the satisfaction of employed women in the tourism sector, as it has been confirmed that women make up a large proportion of tourism employees. Namely, the research emphasizes certain factors that influence the level of employee satisfaction, which can become a strategic starting point in organizing corrective measures for more efficient and effective business and survival in the market. The importance of this research is to find the factors that will affect the satisfaction and loyalty of employees, and thus contribute to the productivity, profitability and competitiveness of enterprises in the tourism market. The paper emphasizes the position and satisfaction of the female workforce, as the highest percentage of women employed in the tourism sector is recorded. The originality of this research work can help empower women in business and create strategic measures to improve the working environment.

Author Contributions: Conceptualization T.G. and M.D.P.; data curation, M.M.R. and D.D.; formal analysis, D.D.; funding acquisition, N.V.Y.; methodology T.G., D.V., M.D.P. and M.M.R.; software, T.G.; investigation, D.V., writing-original draft, T.G. and D.V.; writing-review and editing, T.G., M.D.P. and M.M.R. All authors have read and agreed to the published version of the manuscript.

Funding: The reported study was funded by RFBR (Project no. 19-29-07400 mk).

Institutional Review Board Statement: Not suitable.

Informed Consent Statement: Not suitable.

Data Availability Statement: Not applicable.

Conflicts of Interest: The authors declare no conflict of interest.

\section{References}

1. Ladkin, A.; Buhalis, D. Online and social media recruitment: Hospitality employer and prospective employee considerations. Int. J. Contemp. Hosp. Manag. 2016, 28, 327-345. [CrossRef]

2. Yeh, C.-M. Tourism involvement, work engagement and job satisfaction among frontline hotel employees. Ann. Tour. Res. 2013, 42, 214-239. [CrossRef]

3. Baum, T.; Kralj, A.; Robinson, R.-N.; Solnet, D.J. Tourism workforce research: A review, taxonomy and agenda. Ann. Tour. Res. 2016, 60, 1-22. [CrossRef]

4. Risman, B. Gender as a social structure: Theory wrestling with activism. Gend. Soc. 2004, 18, 429-451. [CrossRef]

5. Risman, B. Gender Vertigo: American Families in Transition; Yale University Press: New Haven, CT, USA, 1998.

6. Robbins, S.; Judge, T.A. Organizational Behavior, 12th ed.; Prentice-Hall: Upper Saddle River, NJ, USA, 2007.

7. Gajić, T.; Petrović, D.M.; Blešić, I.; Radovanović, M.; Syromjatnikowa, J. The impacts of fears in making travel decisions: COVID-19 vs. lack of money. J. Tour. Futures 2021, in press. [CrossRef]

8. Christen, M.; Soberman, D.; Iyer, G. Job Satisfaction, Job Performance, and Effort: A Reexamination Using Agency Theory. J. Mark. 2006, 70, 137-150. [CrossRef]

9. Dossiers, Digithale Bibliothek. Available online: https://sites.google.com/a/nf-int.org/digitale-bibliothek/home/tourismus / dossiers (accessed on 16 May 2021).

10. Segovia-Perez, M.; Figueroa-Domecq, C. Women and Senior Management in the Tourism Sector; Synthesis, Dialnet: Madrid, Spain, 2014.

11. Elaine, C.; Catheryn, K.; Charles, A. A systematic literature review of risk and gender research in tourism. Tour. Manag. 2017, 58, 89-100. [CrossRef]

12. Yang, E.C.-L.; Tavakoli, R. Tourism and Asian Genders; Channel View: Bristol, UK, 2016; pp. 23-39.

13. Santero-Sanchez, R.; Segovia-Perez, M.; Castro-Nunez, B.; Figueroa-Domecq, C.; Talon-Ballestero, P. Gender differences in the hospitality industry: A Job quality index. Tour. Manag. 2015, 51, 234-246. [CrossRef] 
14. Vazquez, S. The Discourse of Women Leaders; Catedra, Instituto de la Mujer: Madrid, Spain, 2008.

15. Ramos, V.; Rey-Maqueira, J.; Tugores, M. Analisis empírico de discriminacion por razon de genero en una economía especializada en turismo. Ann. Tour. Res. 2002, 4, 239-258.

16. Pleck, J.H. The Work family role system. Soc. Probl. 1977, 24, 411-421. [CrossRef]

17. Ramchurjee, N. Tourism a Vehicle for Women's Empowerment: Prospect and Challenges, Project: Local Residents and impacts on Ecotourism; University of Mysore: Manasagangotri, India, 2011.

18. Alrwajfah, M.M.; Almeida-García, F.; Cortés-Macías, R. Females' perspectives on tourism's impact and their employment in the sector: The case of Petra, Jordan. Tour. Manag. 2020, 78, 104069. [CrossRef]

19. Jayswal, D.K.; Jaiswal, M. Women's participation and Tourism industry: An overview. Int. J. Humanit. Soc. Sci. 2015, 6, 269-273. [CrossRef]

20. Krishna Kumari, J. Woman Empowerment through Entrepreneurship in Service Sector with special Reference to SHGs in Tourism. Glob. J. Res. Anal. 2014, 3, 155-160.

21. Çiçek, D.; Zencir, E.; Kozak, N. Women in Turkish tourism. J. Hosp. Tour. Manag. 2017, 31, 228-234. [CrossRef]

22. Abou-Shouk, M.-A.; Mannaa, M.-T.; Elbaz, A.-M. Women's empowerment and tourism development: A cross-country study. Tour. Manag. Perspect. 2021, 37, 100782. [CrossRef]

23. Aghazamani, Y.; Hunt, C. Beyond historical adversaries: Exploring new grounds for peace through tourism between Iran and the US. Tour. Cult. Commun. 2015, 15, 59-64. [CrossRef]

24. Boley, B.; Maruyama, N.; Woosnam, K. Measuring empowerment in an Eastern context: Findings from Japan. Tour. Manag. 2015, 2015. 50, 112-122. [CrossRef]

25. Figueroa-Domecq, C.; De Jong, A.; Williams, A. Gender, tourism \& entrepreneurship: A critical review. Ann. Tour. Res. 2020, 84, 102980. [CrossRef]

26. Somarriba, S.; Merino, M.C.; Negro, A. The Quality of Employment in Spain: An Analysis from the Gender Perspective; Jornadas de Economía Laboral (AETT): Madrid, Spain, 2013.

27. Poulston, J.M. Working conditions in hospitality: Employees' views of the dissatisfactory hygiene factors. J. Qual. Assur. Hosp. Tour. 2009, 10, 23-43. [CrossRef]

28. Yousef, D.-A. Organizational commitment: A mediator of the relationships of leadership behavior with job satisfaction and performance in a nonwestern country. J. Manag. Psychol. 2000, 15, 6-16. [CrossRef]

29. Mercurio, Z.-A. Affective Commitment as a Core Essence of Organizational Commitment an Integrative Literature Review. Hum. Resour. Dev. Rev. 2015, 14, 389-414. [CrossRef]

30. Thrane, C. Earnings differentiation in the tourism industry: Gender, human capital and socio-demographic effects. Tour. Manag. 2008, 29, 514-524. [CrossRef]

31. Baum, T. Human resources in tourism: Still waiting for change. Tour. Manag. 2007, 28, 1383-1399. [CrossRef]

32. Duenas, D.; Iglesias, C.; Llorente, R. Job quality, job satisfaction and services in Spain. J. Innov. Econ. 2010, 5, 145-166. [CrossRef]

33. Bender, K.-A.; Donohuet, S.-M.; Heywoods, H.-S. Job satisfaction and gender segregation. Oxf. Econ. Pap. 2005, 57, 479-496. [CrossRef]

34. Panaccio, A.; Vandenberghe, C. Perceived organizational support, organizational commitment and psychological well-being: A longitudinal study. J. Vocat. Behav. 2009, 75, 224-236. [CrossRef]

35. Caillier, J.G. Does Public Service Motivation Mediate the Relationship between Goal Clarity and both Organizational Commitment and Extra-Role Behaviours? Public Manag. Rev. 2016, 2016. 18, 300-318. [CrossRef]

36. Jong, J.; Ford, M.T. The Lagged Effects of Job Demands and Resources on Organizational Commitment in Federal Government Agencies: A Multi-Level Analysis. J. Public Adm. Res. Theory 2016, 26, 475-492. [CrossRef]

37. Gajić, T.; Penić, M.; Vujko, A.; Petrović, M.D. Development Perspectives of Rural Tourism Policy—Comparative Study of Rural Tourism Competitiveness Based on Perceptions of Tourism Workers in Slovenia and Serbia. East. Eur. Countrys. 2018, 24, 144-154. [CrossRef]

38. Krakover, S. Partitioning seasonal employment in the hospitality industry. Tour. Manag. 2000, 21, 461-471. [CrossRef]

39. Judge, T.A.; Heller, D.; Mount, M.K. Five-factor model of personality and job meta-analysis. J. Appl. Psychol. $2002,87,530-541$. [CrossRef] [PubMed]

40. Takeuchi, R.; Chen, G.; Lepak, D.P. Through the looking glass of a social system: Cross-level effects of high performance work systems on employee attitudes. Pers. Psychol. 2009, 62, 1-29. [CrossRef]

41. Klein, H.J.; Molloy, J.C.; Brinsfield, C.T. Reconceptualizing workplace commitment to redress a stretched construct: Revisiting assumptions and removing confounds. Acad Manag. Rev. 2012, 37, 130-151. [CrossRef]

42. Becker, H.-S. Notes on the concept of commitment. In Sociological Work, 1st ed.; Routledge: Milton Park, UK, 2017; ISBN 9781315129983. [CrossRef]

43. Mowday, R.T.; Steers, R.M.; Porter, L.W. The measurement of organizational commitment. J. Vocat. Behav. 1979, 14, 224-247. [CrossRef]

44. Meyer, J.P.; Allen, N.J.; Gellatly, I.R. Affective and continuance commitment to the organization: Evaluation of measures and analysis of concurrent and time-lagged relations. J. Occup. Psychol. 1990, 75, 710-720. [CrossRef]

45. Meyer, J.P.; Allen, N.J. A three-component conceptualization of organizational commitment. Hum. Resour. Manag. Rev. 1991, 1 , 61-89. [CrossRef] 
46. Meyer, J.P.; Allen, N.J. Testing the side-bet theory of organizational commitment: Some methodological consid-erations. J. Appl. Psychol. 1984, 69, 372-378. [CrossRef]

47. Becker, H.S. Notes on the concept of commitment. Am. J. Sociol. 1960, 66, 32-40. [CrossRef]

48. Allen, N.J.; Meyer, J.P. The measurement and antecedents of affective, continuance and the measurement and antecedents of affective, continuance and normative commitment to the organization. J. Occup. Psychol. 1990, 63, 1-18. [CrossRef]

49. Allen, N.J.; Meyer, J.P. Affective, continuance, and normative commitment to the organization: An examination of construct validity. J. Vocat. Behav. 1996, 49, 252-276. [CrossRef]

50. Cheng, Y.; Stockdale, M.S. The validity of the three-component model of organizational commitment in a Chinese context. J. Vocat. Behav. 2003, 62, 465-489. [CrossRef]

51. Dunham, R.B.; Grube, J.A.; Castaneda, M.B. Organizational commitment: The utility of an integrative definition. J. Appl. Psychol. 1994, 79, 370-380. [CrossRef]

52. Cohen, A. Commitment before and after: An evaluation and reconceptualization of organizational commitment. Hum. Resour. Manag. Rev. 2007, 17, 336-354. [CrossRef]

53. AL-Jabari, B.; Ghazzawi, I. Organizational Commitment: A Review of the Conceptual and Empirical Literature and a Research Agenda. Int. Leadersh. J. 2019, 11, 78-119.

54. Klein, H.-J.; Cooper, J.-T.; Molloy, J.-C.; Swanson, J.-A. The assessment of commitment: Advantages of a unidimensional, target-free approach. J. Appl. Psychol. 2014, 99, 222-238. [CrossRef] [PubMed]

55. Kehoe, R.R.; Wright, P.M. The impact of high-performance human resource practices on employees' attitudes and behaviors. $J$. Manag. 2013, 39, 366-391. [CrossRef]

56. Huang, M.; Li, P.; Meschke, F.; Guthrie, J.P. Family firms, employee satisfaction, and corporate performance. J. Corp. Finance 2015, 34, 108-127. [CrossRef]

57. Lee, T.W.; Hom, P.W.; Eberly, M.B.; Li, J.; Mitchell, T.R. On the next decade of research in voluntary employee turnover. Acad. Manag. Perspect. 2017, 31, 201-221. [CrossRef]

58. Kong, H.; Jiang, X.; Chan, W.; Zhou, X. Job satisfaction research in the field of hospitality and tourism. Int. J. Contemp. Hosp. Manag. 2018. [CrossRef]

59. Aghazamani, Y.; Kerstetter, D.; Allison, P. Women's perceptions of empowerment in Ramsar, a tourism destination in northern Iran. Women's Stud. Int. Forum 2020, 79, 102340. [CrossRef]

60. Hunter Powell, P.; Watson, D. Service unseen: The hotel room attendant at work. Int. J. Hosp. Manag. 2006, 25, 297-312. [CrossRef]

61. Zhao, X.; Ghiselli, R. Why do you feel stressed in a "smile factory"? Hospitality job characteristics influence work-family conflict and job stress. Int. J. Contemp. Hosp. Manag. 2016, 28, 305-326. [CrossRef]

62. Tom, B. Human resources in tourism: Still waiting for change? e A 2015 reprise. Tour. Manag. 2015, 50, 204-212. [CrossRef]

63. Long, R. The impact of new office information technology on job quality of female and male employees. Hum. Relat. 1993, 46, 939-961. [CrossRef]

64. Kara, D.; Uysal, M.; Magnini, V.-P. Gender differences on JSof the five-star hotel employees: The case of the Turkish hotel industry. Int. J. Hosp. Manag. 2012, 20, 1047-1065. [CrossRef]

65. Anker, R.; Chernyshev, I.; Egger, P.; Mehran, F.; Ritter, J.A. Measuring Decent Work with Statistical Indicators; International Labour Office, Policy Integration Working Paper Retrieved from International Labour Organization; World Health Organization WHO Public Services International PSI: Geneva, Switzerland, 2003.

66. Vujko, A.; Tretiakova, N.T.; Petrović, M.; Radovanović, M.; Gajić, T.; Vuković, D. Women's empowerment through selfemployment in tourism. Ann. Tour. Res. 2018, 76, 328-330. [CrossRef]

67. Panagiotis, S.; Nikolaos, K.; Konstantinos, C.; Dimitrios, B. Job satisfaction and employee turnover determinants in high contact services: Insights from Employees' Online reviews. Tour. Manag. 2019, 75, 130-147. [CrossRef]

68. Gentry, K.M. Belizean women and tourism work: Opportunity or impediment? Ann. Tour. Res. 2007, 34, 477-496. [CrossRef]

69. Kinnaird, V.; Hall, D. Understanding tourism processes: A gender-aware framework. Tour. Manag. 1996, 17, 95-102. [CrossRef]

70. Munoz-Bullon, F. The gap between male and female pay in the Spanish tourism industry. Tour. Manag. 2009, 30, 638-649. [CrossRef]

71. Martins, H.; Proença, T. Minnesota satisfaction questionnaire-psychometric properties and validation in a population of Portuguese hospital workers. J. Econ. Manag. Strateg. 2012, 471, 1-23. [CrossRef]

72. Kuruüzüm, A.; Cetin, E.I.; Irmak, S. Path analysis of organizational commitment, job involvement and job satisfaction in the Turkish hospitality industry. Tour. Rev. 2009, 64, 4-16. [CrossRef]

73. Khan, K.; Nemati, A.-L. Impact of job involvement on employee satisfaction: A study based on medical doctors working at Riphah International University Teaching Hospitals in Pakistan. Afr. J. Bus. Manag. 2011, 5, 2241-2246. [CrossRef]

74. Niki, G.; Evangelos, G.; Panagiotis, M. Practical application of MSQ and MUSA methodology in determining critical job satisfaction factors of seasonal employees in summer destination luxury resorts. Tour. Manag. 2019, 74, 426-437.

75. Frye, W.D. An examination of JSof hotel front office managers according to extrinsic, intrinsic, and general motivational factors. Int. J. Bus. Soc. Sci. Res. 2012, 13, 40-52. [CrossRef]

76. Meyer, J.P.; Allen, N.J.; Topolnytsky, L. Commitment in a changing world of work. Can. Psychol./Psychol. Can. 1998, 39, 83-93. [CrossRef] 
77. Gajić, T.; Petrović, D.M.; Radovanović, M.; Tretiakova, T.N.; Syromjatnikowa, J.A. Possibilities of Turning Passive Rural Areas into Tourist Attractions Through Attained Service Quality. Eur. Countrys. J. 2020, 12, 179-276. [CrossRef]

78. Baig, S.A.; Iqbal, S.; Abrar, M.; Amjad, F.; Zia-ur-Rehman, M.; Awan, M.U. Impact of leadership styles on employees' performance with moderating role of positive psychological capital. Total Qual. Manag. Bus. Excell. 2019, 32, 1085-1105. [CrossRef]

79. Charlesworth, S.; Welsh, J.; Strazdins, L.; Baird, M.; Campbell, I. Measuring poor job quality amongst employees: The VicWAL job quality index. Labour Ind. J. Soc. Econ. Relat. Work 2014, 24, 103-123. [CrossRef]

80. Royuela, V.; Surinach, J. Quality of work and aggregate productivity. Soc. Indic. Res. 2013, 113, 37-66. [CrossRef]

81. Mathieu, J.E.; Zajac, D.-M. A review and meta-analysis of the antecedents, correlates, and consequences of organizational commitment. Psychol. Bull. 1990, 108, 171-194. [CrossRef]

82. Powell, D.M.; Meyer, J.P. Side-bet theory and the three-component model of organizational commitment. J. Vocat. Behav. 2004, 65, 157-177. [CrossRef]

83. Ćulibrk, J.; Delić, M.; Mitrović, S.; Ćulibrk, D. Job Satisfaction, Organizational Commitment and Job Involvement: The Mediating Role of Job Involvement. Front. Psychol. 2018, 9, 132. [CrossRef] [PubMed]

84. Eliyana, A.; Muzakki, S.-M. Job satisfaction and organizational commitment effect in the transformational leadership towards employee performance. Eur. Res. Manag. Bus. Econ. 2019, 4, 144-150. [CrossRef]

85. Ogbeide, G.C.A.; Harrington, R.J. The relationship among participative management style, strategy implementation success, and financial performance in the foodservice industry. Int. J. Contemp. Hosp. Manag. 2011, 23, 719-738. [CrossRef]

86. Chuang, N.K.; Yin, D.; Dellman-Jenkins, M. Intrinsic and extrinsic factors impacting casino hotel chefs' job satisfaction. Int. J. Contemp. Hosp. Manag. 2008, 21, 323-340. [CrossRef]

87. Meyer, J.P.; Allen, N.J. Commitment in the Workplace: Theory, Research, and Application; SAGE Publications Inc.: Thousand Oask, CA, USA, 1997. [CrossRef]

88. Mathur, G.; Salunke, M. Organizational commitment and Job Satisfaction: A study of Manufacturing. APOTHEOSIS: Tirpude's (TNBJR). Nat. J. Bus. Res. 2013, 4, 129-143. [CrossRef]

89. Mabasa, F.D.; Mabasa, E.L.; Netshidzivhani, M.V. The relationship between job satisfaction and organizational commitment among academic staff members in a selected higher education institution. In Proceedings of the WEI International Academic Conference, Vienna, Austria, 11-15 April 2016.

90. Ambad, S.; Rimin, F.; Harbi, A. Determinant of Organizational Commitment among Women Employees in Malaysia. Int. J. Acad. Res. Bus. Soc. Sci. 2017, 10, 220-229. [CrossRef]

91. Swati, A.; Shalini, S. Organizational Commitment \& Career Satisfaction among Women Employees. Indian J. Ind. Relat. 2019, 54, 20-30. 